\title{
STUDI KASUS : STATUS NEUROLOGI PASIEN SPACE OCCUPYING LESION DENGAN HIV dan TOXOPLASMOSIS CEREBRI
}

\author{
Ade Iwan Mutiudin ${ }^{1}$, Ridal Sagala ${ }^{2}$, Tuti Pahria ${ }^{3}$, Yusshy Kurnia Herliani ${ }^{4 *}$, \\ Hasniatisari Harun ${ }^{5}$, Epi Pitriana ${ }^{6}$ \\ 1,2,3,4,5Fakultas Keperawatan, Universitas Padjadjaran \\ ${ }^{6}$ Ruang Azalea, RSUP Hasan Sadikin Bandung \\ E-mail: *yusshy.kurnia@unpad.ac.id
}

\begin{abstract}
Abstrak
Space occupying lesion merupakan desakan ruang yang diakibatkan peningkatan volume di dalam ruang intrakranial. Desakan ruang di intrakranial dapat mengakibatkan jaringan otak mengalami nekrosis sehingga dapat menyebabkan gangguan neurologik progresif. Pasien SOL dengan HIV dan Toxoplasmosis Cerebri menunjukkan hampir 80-90\% ditemukan memiliki kelainan neurologik. Tujuan : menganalisis karakteristik pasien dan menganalisis status neurologi. Metode : penelitian dekriptif dengan pendekatan studi kasus observasi. Tehnik pengambilan sampel yang digunakan adalah consecutive sampling. Alat pengumpulan data menggunakan lembaran ceklis yang merupakan kriteria status neurologis berdasarkan Nanda, lembar observasi dan MMSE. Hasil : Durasi mulai sakit yang di alami kedua pasien lebih dari 3 bulan dengan lama hari perawatan lebih dari 7 hari. Kedua pasien mempunyai riwayat penyakit penyerta yang sama dan baru mendapatkan terapi Atiretroviral setelah dirawat di rumah sakit. Gangguan status neurologis yang paling dominan tampak pada pasien Space Occupying Lesion dengan HIV dan Toxoplasmosis Cerebri diantaranya : Keluhan sakit kepala, gangguan kognitif dan gangguan berbicara serta kelemahan otot. Saran : Monitoring status neurologi secara komprehensif merupakan bagian penting terutama pada pasien Space Occupying Lesion dengan HIV dan Toxoplasmosis Cerebri, agar pelayanan yang diberikan akan lebih optimal dan berkualitas. Sehingga dapat mengurangi angka morbiditas dan mortalitas yang diakibatkan oleh gangguan fungsi neurologi.
\end{abstract}

Kata Kunci : HIV, Status Neurologi, Space Occupying Lesion, Toxoplasmosis Cerebri

\begin{abstract}
Case Study : Neurology Status of Patients Space Occupying Lesion with HIV and Cerebri Toxoplasmosis. Space occupying lesion is the insistence of space caused by an increase in volume in the intracranial space. Pressure in the intracranial space can brain tissue to experience necrosis so that it can cause progressive neurologic disorders. SOL patients with HIV and Cerebri Toxoplasmosis show nearly 80-90\% are found to have neurological abnormalities. Aims : To analyze patient characteristics and analyze neurological status. Method : Descriptive research with an observational case study approach. The sampling technique used was consecutive sampling. Data collection tools use checklist sheets which are neurological status criteria based on Nanda, observation sheets and MMSE. Results : Duration of pain started in both patients was more than 3 months with a length of treatment more than 7 days. Both patients had a history of the same comorbidities and had only received Atiretroviral therapy after being hospitalized. The most dominant neurological status disorders seen in Space Occupying Lesion patients with HIV and Cerebri Toxoplasmosis include: Complaints of headaches, cognitive disorders and speech disorders and muscle weakness. Suggestion: Monitoring Neurology Status comprehensively is an important part especially in the patient's occupying lesion with HIV, so that the service provided will be more optimal and quality. Thus, it can reduce the morbidity and mortality rates caused by impaired neurological functions.
\end{abstract}

Keywords: HIV, Neurological Status, Space Occupying Lesion, Cerebral Toxoplasmosis 


\section{Pendahuluan}

Space Occupying Lesion (SOL) merupakan desakan ruang yang diakibatkan peningkatan volume di dalam ruang intrakranial yang ditempati oleh jaringan otak, darah, dan cairan serebrospinal. Lesi desakan ruang (Space Occupying Lesion) bisa meningkatkan tekanan intrakranial (Wilson, L.M., \& Price, S.A, 2006). Space Occupying Lesion bisa berupa neoplasma ataupun tumor, perdarahan ataupun granuloma. Jaringan otak akan mengalami nekrosis sehingga menyebabkan gangguan neurologik progresif (Sisca \& Zam, 2017).

SOL dengan immunocompromise seperti pada pasien HIV merupakan suatu keadaan adanya defisiensi imun yang disebabkan oleh defisiensi yang progresif dari limfosit $\mathrm{T}$ ( $\mathrm{T}$ helper), pasien dengan penurunan CD4 di bawah level kritis (CD4<200sel/ul). Keadan ini menjadikan pasien sangat rentan terhadap infeksi oportunistik (Yostila D \& Armen A, 2018). Toxoplasma merupakan salah satu infeksi opportunistik yang paling sering ditemukan pada pasien dengan HIV (Abdul Gofir, 2018). Toxoplasmosis termasuk dalam peringkat 10 besar penyakit oportunistik yang paling sering ditemukan pada pasien keganasan dan HIV terutama dengan Cluster of Differentiation (CD4) di bawah 200sel/ul (Amin Z et.,al 2013).

Pasien dengan HIV dan Toxoplasmosis Cerebri 60\% menunjukkan tanda SOL dan hampir 80-90\% ditemukan memiliki kelainan neurologik, dimana diyakini memicu toksin atau limfokin yang mengakibatkan disfungsi seluler dan mengganggu fungsi neurotransmitter, yang ditandai dengan penurunan progressif pada fungsi kognitif, perilaku dan gangguan motorik. Komplikasi SOL dengan HIV dan Toxoplasmosis Cerebri menyebabkan morbiditas yang cukup besar dan seringkali terkait dengan angka kematian yang tinggi (Mohammed MZ \& Venugopal K, 2014).

Penelitian yang dilakukan di Rumah Sakit Massachusetts Belanda pada bulan Oktober 1998 sampai April 2002 dari 63 pasien terdapat 62 pasien $(98 \%)$ mengalami prognosis yang buruk karena memiliki satu atau lebih faktor resiko yaitu gejala fokal neurologis, kesadaran menurun dan kejang (De Beek, 2004). Sedangkan penelitian di RS Cipto Mangunkusumo Jakarta pada bulan Januari 1997 Desember 2005 menunjukkan hubungan peningkatan angka mortalitas dengan kejadian penurunan kesadaran dan gejala fokal neurologis lainnya. 273 pasien $41 \%$ diantaranya memiliki prognosis yang buruk akibat adanya defisit neurologis saat masuk rumah sakit (Hendrik dan Jofizal, 2006).

Berdasarkan masalah keperawatan tersebut maka perlu dilakukan monitoring status neurologi pasien secara komprehensif dan berkala yang bertujuan untuk menganalisa status neurologi sehingga dapat mempertahankan status neurologi yang adekuat pada pasien SOL dengan HIV dan Toxoplasmosis Cerebri sehingga pelayanan yang diberikan akan lebih optimal dan berkualitas.

Menganalisis karakteristik demograpi pasien space occupying lesion dengan HIV dan toxoplasmosis cerebri. Menganalisis status neurologi pasien space occupying lesion dengan HIV dan toxoplasmosis cerebri

\section{Metode Penelitian}

Metode penelitian yang digunakan adalah penelitian dekriptif dengan pendekatan studi kasus observasi. Studi kasus dilaksanakan di ruang azalea RSHS Bandung pada Bulan November 2019. Sampel pada penelitian terdiri dari dua orang pasien space occupying lesion dengan HIV dan toxoplasmosis cerebri. Tehnik pengambilan sampel yang digunakan adalah consecutive sampling, dimana pemilihan sampel dengan menetapkan subjek yang memenuhi kriteria inklusi dimasukan dalam penelitian sampai kurun waktu tertentu, sehingga jumlah klien yang diperlukan terpenuhi (Nursalam 
2017). Kriteria inklusi dari studi kasus adalah pasien dewasa atau lanjut usia dengan gangguan status neurologi.

Teknik pengumpulan data yaitu langkah pertama yang dilakukan peneliti adalah memberikan lembar persetujuan untuk dijadikan responden dalam penelitian. Informed consent dilakukan kepada pasien dan keluarga agar mengerti maksud dan tujuan peneliti serta mengetahui apa yang akan kita teliti, hasil apa yang akan kita peroleh nanti. Apabila pasien dan keluarga bersedia untuk dijadikan responden penelitian, maka responden mengisi lembar persetujuan yang telah disediakan, sebaliknya jika calon responden tidak bersedia maka peneliti akan menghormati hak responden.

Alat pengumpulan data dan pengkajian menggunakan lembar ceklis yang merupakan kriteria status neurologis berdasarkan nanda, lembar observasi dan pengkajian mini-mental state exam (MMSE). Kuesioner keperawatan terdiri dari data demografi mengenai durasi mulai sakit, lama hari rawat, dan riwayat penyakit penyerta serta lama pemberian terapi ARV. Data dasar yang didapatkan dalam penelitian ini adalah hasil dari pengkajian asuhan keperawatan secara komprehensif, masalah keperawatan, dan implementasi keperawatan sesuai dengan keadaan pasien. Kemudian dilakukan observasi status neurologi selama 5 hari. Lembar ceklis yang merupakan kriteria status neurologi berdasarkan nanda dan juga penilaian (MMSE) RSHS. Jenis observasi yang kami lakukan diantaranya :

1. Tanda-tanda vital

2. Pupil

3. Tingkat kesadaran

4. Glasgow Coma Scale

5. Status kognitif (MMSE)

6. Status pernafasan

7. Keluhan sakit kepala

8. Karakteristik berbicara

9. Kekuatan otot

10. Muntah

11. Kejang
Sumber : Nursing intervention

clasificaion (NIC)

\section{Hasil Penelitian}

\section{Pasien I}

Tuan. I, berusia 31 tahun, keluarga pasien mengeluhkan 3 hari sebelum masuk rumah sakit pasien mengeluh nyeri kepala hebat, pasien banyak tidur dan sulit untuk dibangunkan. Pasien dibawa ke Rumah Sakit dalam keadaan penurunan kesadaran. Riwayat penyakit sebelumnya bahwa 3 tahun terakhir pasien sudah sering mengeluh sakit kepala tetapi pasien tidak berobat ke rumah sakit. Hasil pememeriksaan penunjang MRI Kepala, kesan: Intracerebral pre-kontras tampak hipointensitas multiple intracerebral terutama di temporo-parietal kanan serta forceps major kanan yang post kontras terlihat irreguler rim enhancing massa di temporo-parietal kanan juga di forceps major kanan dengan perifokal edema yang menyempitkan sulcy dan gyri serta mengobliterasi ventrikel lateral kanan dan III, serta sylvia fissure kanan dengan medline shifted ringan ke kiri. dd/: toxoencephalitis/TORCH, tidak tampak tandatanda cerebral atriphi, cerebellum, pons dan cerebellopontine angle baik. Rhinosinusitis ethmoidalis bilateral dan sphenoidalis kanan. Dilakukan pemeriksaan CD4 Hasilnya: CD4 $=3$, Pemeriksaan anti HIV hasilnya: Reaktif.

Setelah dilakukan pengkajian secara komprehensif mengenai pemeriksaan fisik dan pengkajian status neurologi didapatkan bahwa kesadaran pasien kompos mentis, pasien berbicara pelo dan lambat, daya ingat pasien menurun, pasien tidak mengingat apa-apa, masih terasa nyeri kepala dengan skala nyeri 3-4 (VAS), ekstremitas bagian kiri tampak hemiparase ringan, kekuatan otot kanan 4/4, kiri 3/3. Masalah keperawatan yang muncul di perawatan hari ke 12 adalah resiko ketidakefektifan perfusi jaringan serebral, nyeri kronis dan hambatan memori. 


\section{Pasien II}

Tuan Y, usia 31 tahun, datang ke Rumah Sakit di antar keluarganya kemudian dirawat di ruang Azalea. Pada saat dilakukan pengkajian pasien mengeluh nyeri kepala sejak 3 bulan yang lalu. Semakin hari nyerinya semakin berat, nyeri terasa seperti ditusuk-tusuk, dirasakan hampir setiap hari terutama pada saat bangun tidur dipagi hari, skala nyeri 3 (NRS). Mual(-), muntah (-), kejang (-). Pasien mengeluhkan penglihatan mata kanan kabur, keluhan tersebut dirasakan secara perlahan, pasien juga mengeluh lemah pada sisi badan terutama bagian sebelah kiri. Dua minggu sebelum masuk Rumah Sakit pasien pernah memeriksakan keadaanya ke RS Swasta yang ada di kota Bandung dan tidak mengalami perbaikan sehingga di rujuk ke RSHS. Tn. Y mempunyai riwayat DM yang tidak terkontrol. Pemeriksaan fisik pasien didapatkan kesadaran compos mentis. Tekanan darah 110/70 $\mathrm{mmHg}$, respirasi 22 $\mathrm{x} / \mathrm{mnt}$, pulse $80 \mathrm{x} / \mathrm{mnt}$, suhu $36.4^{\circ} \mathrm{C}$. Pemeriksaan status generalis pasien didapatkan sistem respirasi, cardiovaskuler, gastrointestinal dan genetalia dalam batas normal.

Pada pemeriksaan neurologis nervus kranial terdapat kelainan pada nervus II visus menurun 2/60 bedsite - 3/60 bedsite, nervus III, VI gerakan bola mata opthalmoplegia, diameter pupil kanan 3 $\mathrm{mm}$ kiri $3 \mathrm{~mm}$ dan nervus XI reflek patella (-), parese sinistra. Hasil pemeriksaan mini mental status examination (MMSE) kemungkinan adanya gangguan kognitif dengan skor 23. Dari hasil anamnesis, pemeriksaan fisik dan penunjang maka ditegakan diagnosis etiologi space occupying lesion dengan HIV dan toxoplasmosis cerebri. Pasien ini diberikan terapi Paracetamol Tab, Cotrimoxazole, Fluconazole, Insulin kemudian diberikan intervensi sesuai keadaan pasien sampai mengalami pemulihan kesehatan.

Tabel 1.

Karakteristik Demograpi Pasien I dan Pasien II

\begin{tabular}{clll}
\hline NO & \multicolumn{1}{c}{ KETERANGAN } & PASIEN I & PASIEN II \\
\hline 1 & Nama & Tuan I & Tuan Y \\
2 & Usia & 31 Tahun & 32 Tahun \\
3 & Jenis kelamin & Laki-laki & Laki-laki \\
4 & Durasi mulai sakit & 3 Tahun & 3 Bulan \\
5 & Lama hari rawat & 18 Hari & 8 Hari \\
6 & Penyakit penyerta & Toxoplasmosis cerebri & Toxoplasmosis cerebri, DM \\
7 & Terapi ARV & 14 Hari & 5 Hari \\
\hline Sumber $:$ Ruang Azalea RSUP Hasan Sadikin & &
\end{tabular}

Tabel 2.

Lembar Observasi Tuan I

\begin{tabular}{|c|c|c|c|c|c|c|c|c|c|c|c|}
\hline \multirow{3}{*}{ No } & \multirow{3}{*}{ Intervensi } & \multicolumn{10}{|c|}{ Respon } \\
\hline & & \multicolumn{2}{|c|}{ Hari ke-14 } & \multicolumn{2}{|c|}{ Hari ke-15 } & \multicolumn{2}{|c|}{ Hari ke-16 } & \multicolumn{2}{|c|}{ Hari ke-17 } & \multicolumn{2}{|c|}{ Hari ke-18 } \\
\hline & & 08.00 & 14.00 & 08.00 & 14.00 & 08.00 & 14.00 & 08.00 & 14.00 & 08.00 & 14.00 \\
\hline \multirow[t]{6}{*}{1} & Tanda-tanda vital & & & & & & & & & & \\
\hline & Tekanan darah & $110 / 80$ & $110 / 80$ & $110 / 70$ & $110 / 70$ & $110 / 70$ & $110 / 70$ & $110 / 70$ & $110 / 80$ & $120 / 70$ & $120 / 80$ \\
\hline & Nadi & 82 & 80 & 84 & 86 & 76 & 80 & 82 & 80 & 78 & 80 \\
\hline & Pernafasan & 20 & 20 & 20 & 20 & 20 & 20 & 18 & 20 & 20 & 20 \\
\hline & Suhu & 36.5 & 36.5 & 36.8 & 36.7 & 36 & 36.5 & 36.2 & 36.6 & 36.8 & 36.5 \\
\hline & Saturasi O2 & $98 \%$ & $98 \%$ & $97 \%$ & $97 \%$ & $98 \%$ & $98 \%$ & $95 \%$ & $95 \%$ & $99 \%$ & $99 \%$ \\
\hline \multirow[t]{5}{*}{2} & Pupil & & & & & & & & & & \\
\hline & Ukuran & $\begin{array}{l}3 / 3 \\
\mathrm{~mm}\end{array}$ & $\begin{array}{l}3 / 3 \\
\mathrm{~mm}\end{array}$ & $\begin{array}{l}3 / 3 \\
\mathrm{~mm}\end{array}$ & $\begin{array}{l}3 / 3 \\
\mathrm{~mm}\end{array}$ & $\begin{array}{l}3 / 3 \\
\mathrm{~mm}\end{array}$ & $\begin{array}{l}3 / 3 \\
\mathrm{~mm}\end{array}$ & $\begin{array}{l}3 / 3 \\
\mathrm{~mm}\end{array}$ & $\begin{array}{l}3 / 3 \\
\mathrm{~mm}\end{array}$ & $\begin{array}{l}3 / 3 \\
\mathrm{~mm}\end{array}$ & $\begin{array}{l}3 / 3 \\
\mathrm{~mm}\end{array}$ \\
\hline & Bentuk & Bulat & Bulat & Bulat & Bulat & Bulat & Bulat & Bulat & Bulat & Bulat & Bulat \\
\hline & Simetris & $\mathrm{N}$ & $\mathrm{N}$ & $\mathrm{N}$ & $\mathrm{N}$ & $\mathrm{N}$ & $\mathrm{N}$ & $\mathrm{N}$ & $\mathrm{N}$ & $\mathrm{N}$ & $\mathrm{N}$ \\
\hline & Reaktivitas & $\mathrm{N}$ & $\mathrm{N}$ & $\mathrm{N}$ & $\mathrm{N}$ & $\mathrm{N}$ & $\mathrm{N}$ & $\mathrm{N}$ & $\mathrm{N}$ & $\mathrm{N}$ & $\mathrm{N}$ \\
\hline 3 & Tingkat kesadaran & $\mathrm{CM}$ & $\mathrm{CM}$ & $\mathrm{CM}$ & $\mathrm{CM}$ & $\mathrm{CM}$ & $\mathrm{CM}$ & $\mathrm{CM}$ & $\mathrm{CM}$ & $\mathrm{CM}$ & $\mathrm{CM}$ \\
\hline \multirow[t]{4}{*}{4} & Glasgow Coma Scale & 15 & 15 & 15 & 15 & 15 & 15 & 15 & 15 & 15 & 15 \\
\hline & Eye & 4 & 4 & 4 & 4 & 4 & 4 & 4 & 4 & 4 & 4 \\
\hline & Motorik & 6 & 6 & 6 & 6 & 6 & 6 & 6 & 6 & 6 & 6 \\
\hline & Verbal & 5 & 5 & 5 & 5 & 5 & 5 & 5 & 5 & 5 & 5 \\
\hline
\end{tabular}




\begin{tabular}{|c|c|c|c|c|c|c|c|c|c|c|c|}
\hline 5 & Status Kognitif (MMSE) & 17 & 17 & 19 & 19 & 19 & 19 & 22 & 22 & 26 & 26 \\
\hline \multirow[t]{6}{*}{6} & Status pernafasan & & & & & & & & & & \\
\hline & Pola nafas & Teratur & Teratur & Teratur & Teratur & Teratur & Teratur & Teratur & Teratur & Teratur & Teratur \\
\hline & Kecepatan & Reg & Reg & Reg & Reg & Reg & Reg & Reg & Reg & Reg & Reg \\
\hline & Irama & Teratur & Teratur & Teratur & Teratur & Teratur & Teratur & Teratur & Teratur & Teratur & Teratur \\
\hline & Kedalaman & $\mathrm{N}$ & $\mathrm{N}$ & $\mathrm{N}$ & $\mathrm{N}$ & $\mathrm{N}$ & $\mathrm{N}$ & $\mathrm{N}$ & $\mathrm{N}$ & $\mathrm{N}$ & $\mathrm{N}$ \\
\hline & Kesulitan bernafas & - & - & - & - & - & - & - & - & - & - \\
\hline 7 & Keluhan sakit kepala & $+(3-4)$ & $+(3-4)$ & $+(2-3)$ & $+(1-2)$ & $+(0-1)$ & - (0) & - (0) & $-(0)$ & - (0) & $-(0)$ \\
\hline 8 & Karakteristik berbicara & Rero & Rero & Rero & Rero & Rero & Rero & Rero & Rero & Rero & Rero \\
\hline \multirow[t]{2}{*}{9} & Kekuatan otot & $4 / 3$ & $4 / 3$ & $4 / 3$ & $4 / 3$ & $5 / 4$ & $5 / 4$ & $5 / 4$ & $5 / 4$ & $5 / 4$ & $5 / 4$ \\
\hline & & $4 / 3$ & $4 / 3$ & $4 / 3$ & $4 / 3$ & $5 / 4$ & $5 / 4$ & $5 / 4$ & $5 / 4$ & $5 / 4$ & $5 / 4$ \\
\hline 10 & Muntah & - & - & - & - & - & - & - & - & - & - \\
\hline 11 & Kejang & - & - & - & - & - & - & - & - & - & - \\
\hline
\end{tabular}

Tabel 3.

Lembar Observasi Tuan Y

\begin{tabular}{|c|c|c|c|c|c|c|c|c|c|c|c|}
\hline \multirow{3}{*}{ No } & \multirow{3}{*}{ Intervensi } & \multicolumn{10}{|c|}{ Respon } \\
\hline & & \multicolumn{2}{|c|}{ Hari ke-4 } & \multicolumn{2}{|c|}{ Hari ke-5 } & \multicolumn{2}{|c|}{ Hari ke-6 } & \multicolumn{2}{|c|}{ Hari ke-7 } & \multicolumn{2}{|c|}{ Hari ke-8 } \\
\hline & & 08.00 & 14.00 & 08.00 & 14.00 & 08.00 & 14.00 & 08.00 & 14.00 & 08.00 & 14.00 \\
\hline \multirow[t]{6}{*}{1} & Tanda-tanda vital & & & & & & & & & & \\
\hline & Tekanan darah & $110 / 70$ & $110 / 70$ & $110 / 80$ & $110 / 80$ & $120 / 80$ & $120 / 80$ & $120 / 90$ & $120 / 90$ & $120 / 80$ & $120 / 80$ \\
\hline & Nadi & 80 & 85 & 80 & 82 & 78 & 80 & 80 & 80 & 80 & 82 \\
\hline & Pernafasan & 22 & 22 & 21 & 21 & 21 & 21 & 21 & 21 & 22 & 22 \\
\hline & Suhu & 36.4 & 36.5 & 36.6 & 36.6 & 36.6 & 36.7 & 36.7 & 36.7 & 36.7 & 36.8 \\
\hline & Saturasi O2 & $96 \%$ & $96 \%$ & $97 \%$ & $96 \%$ & $97 \%$ & $97 \%$ & $97 \%$ & $97 \%$ & $97 \%$ & $97 \%$ \\
\hline \multirow[t]{5}{*}{2} & Pupil & & & & & & & & & & \\
\hline & Ukuran & $\begin{array}{l}3 / 3 \\
\mathrm{~mm}\end{array}$ & $\begin{array}{l}3 / 3 \\
\mathrm{~mm}\end{array}$ & $\begin{array}{l}3 / 3 \\
\mathrm{~mm}\end{array}$ & $\begin{array}{l}3 / 3 \\
\mathrm{~mm}\end{array}$ & $\begin{array}{l}3 / 3 \\
\mathrm{~mm}\end{array}$ & $\begin{array}{l}3 / 3 \\
\mathrm{~mm}\end{array}$ & $\begin{array}{l}3 / 3 \\
\mathrm{~mm}\end{array}$ & $\begin{array}{l}3 / 3 \\
\mathrm{~mm}\end{array}$ & $\begin{array}{l}3 / 3 \\
\mathrm{~mm}\end{array}$ & $\begin{array}{l}3 / 3 \\
\mathrm{~mm}\end{array}$ \\
\hline & Bentuk & Bulat & Bulat & Bulat & Bulat & Bulat & Bulat & Bulat & Bulat & Bulat & Bulat \\
\hline & Simetris & $\mathrm{N}$ & $\mathrm{N}$ & $\mathrm{N}$ & $\mathrm{N}$ & $\mathrm{N}$ & $\mathrm{N}$ & $\mathrm{N}$ & $\mathrm{N}$ & $\mathrm{N}$ & $\mathrm{N}$ \\
\hline & Reaktivitas & $\mathrm{N}$ & $\mathrm{N}$ & $\mathrm{N}$ & $\mathrm{N}$ & $\mathrm{N}$ & $\mathrm{N}$ & $\mathrm{N}$ & $\mathrm{N}$ & $\mathrm{N}$ & $\mathrm{N}$ \\
\hline 3 & Tingkat kesadaran & $\mathrm{CM}$ & $\mathrm{CM}$ & $\mathrm{CM}$ & $\mathrm{CM}$ & $\mathrm{CM}$ & $\mathrm{CM}$ & $\mathrm{CM}$ & $\mathrm{CM}$ & $\mathrm{CM}$ & $\mathrm{CM}$ \\
\hline \multirow[t]{4}{*}{4} & Glasgow Coma Scale & 15 & 15 & 15 & 15 & 15 & 15 & 15 & 15 & 15 & 15 \\
\hline & Eye & 4 & 4 & 4 & 4 & 4 & 4 & 4 & 4 & 4 & 4 \\
\hline & Motorik & 6 & 6 & 6 & 6 & 6 & 6 & 6 & 6 & 6 & 6 \\
\hline & Verbal & 5 & 5 & 5 & 5 & 5 & 5 & 5 & 5 & 5 & 5 \\
\hline 5 & Status Kognitif (MMSE) & 23 & 23 & 23 & 23 & 26 & 26 & 28 & 28 & 30 & 30 \\
\hline \multirow[t]{6}{*}{6} & Status pernafasan & & & & & & & & & & \\
\hline & Pola nafas & Teratur & Teratur & Teratur & Teratur & Teratur & Teratur & Teratur & Teratur & Teratur & Teratur \\
\hline & Kecepatan & Reg & Reg & Reg & Reg & Reg & Reg & Reg & Reg & Reg & Reg \\
\hline & Irama & Teratur & Teratur & Teratur & Teratur & Teratur & Teratur & Teratur & Teratur & Teratur & Teratur \\
\hline & Kedalaman & $\mathrm{N}$ & $\mathrm{N}$ & $\mathrm{N}$ & $\mathrm{N}$ & $\mathrm{N}$ & $\mathrm{N}$ & $\mathrm{N}$ & $\mathrm{N}$ & $\mathrm{N}$ & $\mathrm{N}$ \\
\hline & Kesulitan bernafas & - & - & - & - & - & - & - & - & - & - \\
\hline 7 & Keluhan sakit kepala & $+(3-4)$ & $+(3-4)$ & $+(3-4)$ & $+(3-4)$ & $+(2-3)$ & $+(2-3)$ & $+(1-2)$ & $+(1-2)$ & $-(0)$ & $-(0)$ \\
\hline 8 & Karakteristik berbicara & Rero & Rero & Rero & Rero & Rero & Rero & Rero & Rero & Rero & Rero \\
\hline \multirow[t]{2}{*}{9} & Kekuatan otot & $5 / 4$ & $5 / 4$ & $5 / 4$ & $5 / 4$ & $5 / 4$ & $5 / 4$ & $5 / 4$ & $5 / 4$ & $5 / 4$ & $5 / 4$ \\
\hline & & $5 / 4$ & $5 / 4$ & $5 / 4$ & $5 / 4$ & $5 / 4$ & $5 / 4$ & $5 / 4$ & $5 / 4$ & $5 / 4$ & $5 / 4$ \\
\hline 10 & Muntah & - & - & - & - & - & - & - & - & - & - \\
\hline 11 & Kejang & - & - & - & - & - & - & - & - & - & - \\
\hline
\end{tabular}

\section{Pembahasan}

\section{Analisis Data Demograpi}

Hasil penelitian ini didapat bahwa kedua responden berjenis kelamin laki-laki dan berusia 31 tahun. Hasil penelitian Ejaz butt, (2005) mengenai analisis morfologi pasien Space Occupying Lesion yang dilakukan oleh Rumah Sakit Lahore, Pakistan, selama 1 tahun didapatkan bahwa dalam 100 kasus space occupying lesion intrakranial, terdapat 54 kasus terjadi pada pria dan 46 kasus pada wanita. Selain itu, pada usia 30-39 tahun terdapat 13 kasus, dan pada usia 40-49 terdapat 14 kasus. Sedangkan menurut hasil dogar (2015) menunjukkan bahwa terdapat 64 (62\%) laki-laki dan 40 (38\%) perempuan. Terlepas dari beberapa perbedaan dalam rasio, semua studi ini menunjukkan penderita laki-laki lebih banyak dibandingkan dengan perempuan.

Durasi mulai sakit yang di alami Tn. I yaitu sekitar 3 tahun yang lalu, pasien sudah sering mengeluh sakit kepala tetapi 
pasien tidak berobat ke rumah sakit. Sedangkan dengan Tn. Y sudah mengalami nyeri kepala selama 3 bulan, Semakin hari nyerinya semakin berat, nyeri terasa seperti ditusuk-tusuk, dirasakan hampir setiap hari terutama pada saat bangun tidur dipagi hari. Durasi mulai sakit mempengaruhi manifestasi klinis yang ditunjukkan oleh pasien.

Suzanne C Smeltzer \& Brenda G
Bare (2012) menerangkan bahwa manifestasi dini dari SOL yang mencakup gangguan daya ingat, sakit kepala, kesulitan berkonsentrasi, konfusi progresif, perlambatan psikomotorik, apatis dan ataksia. Stadium lanjut mencakup gangguan kognitif global, kelambatan dalan respons verbal, gangguan afektif seperti pandangan yang kosong, hiperrefleksi paraparesis spastik, psikosis, halusinasi, tremor, inkontinensia, serangan kejang, mutisme dan kematian. Manifestasi lainnya dapat juga berupa disartria, gangguan kognitif, peningkatan tekanan intrakranial, dan gerakan involunter.

Lama hari perawatan pada tuan I lebih lama yaitu 18 hari perawatan, sedangkan pada tuan $\mathrm{Y}$ lama hari perawatanya selama 8 hari. Pengaruh dari pelayanan medis dalam proses perawatan akan menentukan lama hari rawat pasien. Kondisi fisik pasien dengan sistem imun yang buruk dimana sistem pertahanan manusia terhadap infeksi dari makromolekul asing atau serangan virus, bateri, protozoa, dan parasit terganggu karena penyakit imun sehingga tubuh tidak dapat membentuk anti bodi yang akhirnya memperlama proses penyembuhan bahkan memunculkan penyakit baru. (Djoko wijono, 2000 dalam Ekawati \& Afridah, 2015).

Sedangkan menurut Potter \& Perry, (2006) dalam Kusumayanti et all, (2015) menyatakan bahwa lama perawatan yang memanjang disebabkan karena faktor intrinsik dan ekstrinsik, faktor ekstrinsik diantaranya terdiri dari pemenuhan nutrisi yang tidak adekuat, obat-obatan, teknik operasi. Sedangkan faktor yang kedua adalah faktor intrinsik terdiri dari usia, gangguan sirkulasi, nyeri, dan penyakit penyerta lainya.

Kedua pasien mempunyai riwayat penyakit penyerta yang sama yaitu HIV dan Toxoplasmosis Cerebri. Orang dengan HIV atau AIDS berisiko terkena tumor. Meski belum diketahui alasan pastinya, kemungkinan tumbuhnya tumor jenis ini disebabkan oleh sistem kekebalan tubuh melemah, terutama pada tahap lanjut atau fase akhir HIV/AIDS. Dalam hampir semua kasus, ditemukan virus yang disebut virus Epstein-Barr. diperkirakan sekitar 40\%$50 \%$ SOL intrakranial disebabkan oleh tumor (Ejaz butt, 2005).

Pasien baru menerima terapi antiretroviral setelah dirawat di rumah sakit, tuan I telah mengkonsumsi ARV selama 14 hari, sedangkan tuan $\mathrm{Y}$ baru mendapatkan terapi selama 5 hari. Hasil penelitian Mulyati (2017), menerangkan bahwa dampak pemberian terapi ARV bisa meningkatkan status imunologi dan kelangsungan hidup pasien.

\section{Analisis Status Neurologi}

Hasil pemeriksaan tanda-tanda vital ke dua pasien berada dalam batas normal, tekanan darah sistolik rata-rata 110-120 $\mathrm{mmHg}$, tekanan darah diastolik 70-90 mmHg. Wolf (2019) berpendapat bahwa pentalaksanaan umum mengusahakan tekanan darah yang optimal, tekanan darah yang sangat tinggi dapat menyebabkan edema serebral, sebaliknya jika tekanan darah terlalu rendah akan mengakibatkan iskemia otak dan menyebabkan edema serta peningkatan tekanan intrakranial.

Pemantauan pupil yang dilakukan pada tuan I dan tuan Y mempunyai ukuran yang sama $3 \mathrm{~mm}-3 \mathrm{~mm}$ dengan bentuk bulat, kedua pupil simetris dan adanya reaktivitas terhadap cahaya. Tetapi Tn.Y mengalami pandangan mata kabur dengan kelainan pada nervus II visus menurun $2 / 60$ bedsite - 3/60 bedsite, nervus III, VI gerakan bola mata opthalmoplegia, dan mempunyai 
penyakit penyerta yaitu diabetes melitus yang tidak terkontrol yang mengakibatkan hiperglikemik.

Kadar gula darah yang tinggi (hiperglikemia) kronik pada pasien diabetes berhubungan dengan kerusakan jangka panjang, terjadinya disfungsi atau kegagalan beberapa organ tubuh, terutama mata, ginjal, saraf, jantung dan gangguan vaskuler pembuluh darah (Sudoyo, 2009). Pasien HIV dan Toxoplasmosis Cerebri selain terjadinya kelainan pada otak juga terdapat kelainan lain yang sering terkena yaitu mata sekitar 50\% (Rabaud et al dalam Basavaraju A, 2016). Berbeda dengan penelitian Longmore, (2014) ; Simamora (2017) menyatakan bahwa gangguan penglihatan yang terjadi pada pasien SOL kemungkinan juga disebabkan peningkatan tekanan intrakranial hingga mendesak chiasma optikum sehingga terjadi gangguan penglihatan berupa penurunan visus pada kedua mata.

Muntah dan kejang pada kedua pasien selama observasi tidak pernah terjadi. Tingkat kesadaran GCS dan MMSE. Bahwa dari hasil monitoring tingkat kesadaran dari hari ke 1 sampai hari ke 5 ke dua pasien dalam keadaan compos mentis dengan nilai Glasgow Coma Scale E4, M6, V5. Monitoring ingatan dengan menggunakan Instrument MMSE, hasil pada tuan I terjadi gangguan kognitif, skor hari pertama yaitu 17 , skor hari ke dua dan ketiga 19 dan skor hari ke empat dan lima 22. Pasien mengalami pemulihan selama 5 hari observasi tetapi skor yang didapatkan masih dibawah normal 24-30. Sedangkan hasil MMSE tuan Y, skor pada hari pertama dan kedua 23 dengan interpretasi masih terjadi gangguan kognitif, skor pada hari ke 3 sampai ke lima yaitu 26, 28 dan 29, dimana hasil ini menyatakan bahwa fungsi kognitif pasien mengalami pemulihan dan fungsi kognitif normal. Nilai MMSE dapat dipengaruhi oleh faktor sosiodemograpi yaitu umur, jenis kelamin, tingkat pendidikan, pekerjaan dan status pernikahan. Yang kedua adalah faktor lingkungan (behavior). Seperti stres fisik, kontak sosial, aktivitas fisik, merokok dan minum alkohol (Ismail S. (1992).

Hal tersebut sejalan dengan penelitian yang dilakukan Simamora \& Zanariah, Z. (2017) berpendapat bahwa pasien SOL hasil CT-scan didapatkan gambaran massa yang menyebabkan pergeseran midline shift ke kanan, hipodens dengan batas tegas dan defek ventrikel 3, 4 dengan disertai oedem fokal. Hal tersebut sesuai dengan teori dimana lokasi tumor pada lobus frontalis dapat menyebabkan timbulnya kelemahan lengan dan tungkai kontralateral serta perubahan kepribadian seperti penurunan tingkat intelektual.

Keluhan nyeri kepala. Hasil pemeriksaan nyeri dengan menggunakan Visual Analogi Scale (VAS) kedua pasien mengalami nyeri kepala sedang sampai tidak adanya nyeri kepala. Keluhan nyeri kepala pada tuan I pada hari ke-satu dengan skala Visual Analogi Scale 3-4, hari ke-dua skala vas 2-3, hari ke-tiga pada pemeriksaan pagi hari vas $0-1$ dan siang mengalami pengurangan skala vas 0 pada siang hari sampai dengan observasi hari kelima pasien mengalami penurunan nyeri kepala. Sedangkan pada tuan Y. Nyeri kepala pada hari ke 1 dan 2 vas skala 2-4, hari ke tiga mengalami penurunan nyeri kepala skala vas 2-3, hari ke empat skala nyeri kepala vas 1-2 dan pada hari terakhir pasien sudah tidak mengalami nyeri, pasien terlihat tenang dan tidak menunjukan wajah meringis kesakitan dan terlihat tampak lebih segar. Menurut Longmore, (2014) dalam Simamora, (2017) Gejala klinis fokal maupun umum dari adanya tumor, ditandai dengan adanya peningkatan tekanan intrakranial, hal ini dapat berupa adanya nyeri kepala, muntah tanpa diawali dengan mual, perubahan status mental, meliputi gangguan konsentrasi, cepat lupa, perubahan kepribadian, perubahan mood, berkurangnya inisiatif yang terletak pada lobus frontal atau temporal, ataksia, gangguan keseimbangan, kejang, dan papiledema. 
Sejalan dengan penelitian Yancheva et al.,(2017) menjelaskan bahwa tanda dan gejala SOL dengan HIV dan Toxoplasmosis Cerebri yang sering dirasakan pasien sakit kepala (49-63\%), demam (41-68\%), defisit fokal (22-80\%), kejang (19-29\%), kebingungan (15-52\%), ataxia (15-25\%), letargi (12-44\%), kelemahan saraf kranial (12-19\%), dan gangguan penglihatan (8-15\%). Kemudian hasil menurut Luma et al (2013), dari 97 pasien HIV dengan ET yang diteliti didapatkan sakit kepala merupakan keluhan tersering (92.8\%) diikuti oleh demam $(87,6)$ dan kejang $(57,7 \%)$. Penelitian oleh Goita et al (2012) juga ditemukan hal yang sama yaitu kejang merupakan gejala yang umum ditemukan pada toksoplasmosis cerebri.

Karakteristik berbicara. Hasil monitoring selama lima hari kedua pasien berbicara pelo, lambat dengan intonasi yang tidak jelas. Apabila tumor mengenai bagian kanan dan kiri lobus frontalis, perubahan status mental atau tingkah laku, dan jalan yang tidak terkoordinasi (ataxic gait) dapat terjadi. Bila tumor menekan jaras motorik dapat menimbulkan dysphasia (brocca). Menurut penelitian Nurmufthi G., Y. (2014) disartria merupakan suatu bentuk defisit bahasa yang ditandai gangguan pada artikulasi dan pengucapan kata sedangkan gramatika (tata bahasa), komprehensi dan pemilihan kata tidak terganggu. Hal ini biasanya berarti kesulitan dalam menggerakkan palatum, lidah dan bibir sewaktu berbicara. Beberapa penyebab dari dysarthria diantaranya stroke, cedera kepala, cerebral palsy, dan distrofi otot. Pasien disarankan untuk menjalani rehabilitasi medik, program rehabilitasi medik yang dapat diikuti pasien berupa fisioterapi, terapi wicara dan psikoterapi (Nasution, 2013).

Kaki lemah / hemiparese. Terjadinya kerusakan pada otak kanan menjadi penyebab kelumpuhan tubuh bagian kiri. Pasien dengan kelumpuhan sebelah kiri sering memperlihatkan ketidakmampuan persepsi visiomotor, kehilangan memori visual dan mengabaikan sisi kiri. Sering juga dijumpai kelainan afasia yaitu ketidakmampuan untuk berbahasa dan pemahaman kata atau kalimat dengan baik. Pemeriksaan lanjut yang dilakukan pada kelumpuhan sebelah kiri ditujukan pada fungsi kortikal, subkortikal, batang otak, dan medulla spinalis. Hasil penelitian Cahyati (2013) menjelaskan bahwa kelainan ini biasanya disebabkan karena kerusakan pembuluh darah bagian anterior atau arteri serebral medial yang mengakibatkan infark pada korteks motorik frontalis.

\section{Simpulan dan Saran}

Space Occupying Lesion merupakan penyakit dengan masalah umum mengenai adanya lesi pada ruang intrakranial khususnya yang mengenai otak. Lesi pada otak seperti, hematoma, kontusio serebri, infark, adanya abses otak dan tumor pada intrakranial.

Karakteristik demograpi pasien dalam studi ini adalah mengenai durasi mulai sakit yang di alami kedua pasien lebih dari 3 bulan dengan lama hari perawatan lebih dari 7 hari. Kedua pasien mempunyai riwayat penyakit penyerta yang sama yaitu HIV dan toxoplasmosis cerebri dan baru mendapatkan terapi Atiretroviral setelah dirawat di rumah sakit.

Gangguan status neurologis yang paling dominan tampak pada pasien space occupying lesion dengan HIV dan toxoplasmosis cerebri diantaranya : Keluhan sakit kepala, gangguan kognitif dan gangguan berbicara serta kelemahan otot.

Monitoring status neurologi secara komprehensif merupakan bagian penting terutama pada pasien Space Occupying Lesion dengan HIV dan Toxoplasmosis Cerebri dengan adanya monitoring khusus status neurologi ini diharapkan status neurologi yang adekuat dari setiap pasien sehingga pelayanan yang diberikan akan lebih optimal dan berkualitas. Pelayanan 
yang optimal dan berkualitas diharapkan dapat mengurangi angka morbiditas dan mortalitas yang diakibatkan oleh gangguan fungsi neurologi.

\section{Referensi}

Brunner \& Suddarth. (2000). Asuhan keperawatan dengan gangguan neurlogi: Space Occupying Lesion dengan HIV ec Toxoplasmosis Cerebri. Keperawatan Medikal Bedah. Jakarta: EGC.

Butt, M. E., Khan, S. A., Chaudrhy, N. A., \& Qureshi, G. R. (2005). Intra-cranial space occupying lesions a morphological analysis. Biomedica, 21(1), 31-5.

Dogar, T., Imran, A. A., Hasan, M., Jaffar, R., Bajwa, R., \& Qureshi, I. D. (2015). Space occupying lesions of central nervous system: A radiological and histopathological correlation. Biomedica, 31(1), 15-20.

Ekawati, A., \& Afridah, W. (2015). Hubungan antara lama hari rawat dengan antrian masuk rumah sakit pada pasien bpjs di rs. Islam jemursari surabaya. Journal of Health Sciences, 8(1).

DOI: https://doi.org/10.33086/jhs.v8 i1.223

Foreman, M. D., Fletcher, K., Mion, L. C., Simon, L., \& Faculty, N. (1996). Assessing cognitive function: The complexities of assessment of an individual's cognitive status are important in making an accurate and comprehensive evaluation. Geriatric Nursing, 17(5), 228-232. https://doi.org/10.1016/S01974572(96)80210-2

Guyton A.C. \& J.E. Hall (2007). Buku Ajar Fisiologi Kedokteran. Edisi 9. Jakarta: EGC. 74,76, 80-81, 244, 248, 606,636,1070,1340.

Hartanto H., Susi N., Wulansari P., \& Mahanani DA. (2005). Penyakit
Serebrovaskular. Jakarta: EGC; 2005. BAB 53,; hal. 1106-1129.

Herdman, T. H., \& Kamitsuru, S. (2015). Diagnosis Keperawatan, Definisi \& Klasifikasi 2015-2017 Edisi 10. Jakarta: EGC.

Herlina, H., Kurniati, N., Prawitasari, T., Soedjatmiko, S., Hadinegoro, S. R., Mangunatmadja, I., \& Setyanto, D. B. (2016). Gambaran Fungsi Kognitif HIV Anak yang Telah Memperoleh Terapi Antiretrovirus. Sari Pediatri, 18(2), 100-5.

Jihad, N. H. M., Taufik, R., \& Nurmila, N. (2018). The effect of High Blood Sugar Level of Cataract in Diabetes Mellitus Patient in Eye Health Community Center South Sulawesi. Al-Iqra Medical Journal: Jurnal Berkala Ilmiah Kedokteran, 1(1), $\quad$ 10-15. DOI: https://doi.org/10.26618/aimj.v $1 \mathrm{i} 1.2765$

Kayana, I. B. A., Maliawan, S., \& Kawiyana, I. K. S. (2013). Intracranial Pressure Monitoring Technique. E-Jurnal Medika Udayana, 480-501.

Montoya JG, Toxoplasmosis, In: Goldman L, Schafer Al. (2011).eds.Cecil Medicine. 24th ed.Pholadelphia,PA: Saunders Elseveir; chap 357.

Mulyati, M., Subagio, H. W., \& Udji, M. A. (2017). Hubungan Lama Pemberian Terapi Anti Retroviral dengan Komposisi Tubuh pada Pasien HIV. JNH (journal of nutrition and health), 5(2), 129-137.

NANDA. (2018). Buku diagnosa keperawatan definisi dan klasifikasi 2015-2017. Jakarta: EGC

Nurmufthi G., Y. (2014) dysarthria post stroke attack with uncontrolled hypertension and obesity on a housewife. Jurnal kedokteran; Agromed Unila ; Volume 1 Nomor 2 
Price, SA, \& Wilson, LM. (2006). Patofisiologi : Konsep Klinis ProsesProses Penyakit. Volume 2 Ed/6.

Sadoughil A., Rybinnik I., \& Cohen R. (2013). Measurement and management of Increased intracranial pressure. Crit Care Med 2013;6 (Suppl 1:M4):56-65.

Satyanegara (2010). Ilmu Bedah Saraf Edisi 4. Jakarta: Gramedia Pustaka Utama

Satyanegara (2014). Ilmu bedah saraf satyanegara. Edisi ke-5. Jakarta: PT Gramedia; hlm. 265.

Simamora, S. K., \& Zanariah, Z. (2017). Space Occupying Lesion (SOL). Medical Profession Journal Of Lampung [MEDULA], 7(1), 6873.

Sjamsuhidajat \& de jong. (2010). Buku Ajar Ilmu Bedah.Jakarta: EGC Sjamsuhidajat, R \& Wim, de Jong (ed). 2004.

Smeltzer, Suzanne, C. \& Bare, Brenda G. (2001). Buku Ajar Ilmu Bedah; Keperawatan Medikal Bedah. Jakarta: EGC.

Sri Hastuti, D., \& Zulaikha, F. (2019). Analisis Praktik Klinik Keperawatan pada An. Az dengan Post Operasi Craniotomy atas Indikasi Space Occupying Lesion (SOL) dengan Intervensi Inovasi Penggunaan 2\% Chlorhexidine Gluconate (CHG) sebagai Perawatan Sibin Harian untuk Mengurangi Bakteremia pada Anak yang Dirawat di Ruang PICU RSUD A. Wahab Sjahranie Samarinda Tahun 2019.

Sudoyo, W Aru, Bambang Setiyohadi, Idrus Alwi, Marcellus Simadibrata K, Siti Setiati (2009). Buku Ajar Ilmu
Penyakit Dalam, Jilid III, Edisi V, Jakarta: Interna Publishing

Sumardjono, S. (2004). Perbandingan Skala Keluaran Glasgow Pada Contusio Cerebri Disertai Cedera Kepala Berat Antara Tindakan Craniectomi Dekompresi Dengan Konservatif (Doctoral Dissertation, Program Pendidikan Pasca Sarjana Universitas Diponegoro).

Wilson, L.M., \& Price, S.A. (2006). Patofisiologi: konsep klinis prosesproses penyakit. Edisi ke-6. Volume 2. Jakarta: EGC. Hal. 1232

Wolfe TJ, Torbey MT. (2009). Management of intracranial pressure. Curr Neuro Neurosci Reports;9:47785.

Yancheva N, Tsvetcova N, Marinova I, Elenkov I, Tchervenyakova T, Nikolova M, et al. (2017) A Report of Two Cases with Different Clinical Presentation of Cerebral Toxoplasmosis in HIV-Infected Bulgarian Patient. Journal of AIDS and Clinical Research. 8(673):1-3.; DOI : $10.4172 / 2155-6113.1000673$

Yostila Derosa, Armen Ahmad (2018). Toxoplasmosis Cerebri Pada HIV AIDS, jurnal kesehatan andalas, Vol. 7: ISSN : 2615-1138; DOI: https://doi.org/10.25077/jka.v7 .i0.p96-99.2018

Vidal, J. E. (2019). HIV-related cerebral toxoplasmosis revisited: current concepts and controversies of an old disease. Journal of the International Association of Providers of AIDS Care (JIAPAC), 18, 2325958219867315. https://doi.org/10.1177/2325958219 867315 